\title{
TRANSMISSION \\ AND SCANNING ELECTRON MICROSCOPICAL STUDIES IN THE TEGUMENT OF MALE SCHISTOSOMA MANSONI AFTER OXAMNIQUINE TREATMENT
}

\author{
A. KOHN*, M. L. LÓPEZ-ALVAREZ** and N. KATZ***
}

SUMMARY. Schistosoma mansoni recovered from experimentally infected mice orally treated with oxamniquine were studied by transmission and scanning electron microscopy. The worms were examined 24 hours, 3,7 and 10 days after a single dose of $100 \mathrm{mg} / \mathrm{Kg}$ of the drug. After oxamniquine treatment significant structural alterations were observed in tegumental, muscular and parenchymal levels. The initial alterations were confined to basal vacuolation in the tegument and to structural disorganization both in tegumental and non tegumental cells. Ten days after treatment, intercellular œdema became more prominent originating "bubble-like" lesions with varied dimensions. The intercellular oedema leading to the "bubble" formation seems to be the most striking feature caused by oxamniquine treatment.

\section{Études de microscopie électronique d'émission et de balayage sur le tégu- ment de Schistosoma mansoni mâle après le traitement d'oxamniquine.}

RÉSUMÉ. Nous étudions les Schistosoma mansoni obtenus chez des souris infectées par voie orale et traitées avec l'oxamniquine. Des analyses sous microscopes électroniques d'émission et de balayage ont été faits. Les vers ont été examinés 24 heures, 3,7 , et 10 jours après administration d'une dose simple de $100 \mathrm{mg} / \mathrm{kg}$ d'oxamniquine. Après le traitement, des changements du tégument, du muscle et du parenchyme ont été observés : d'abord une vacuolation basale du tégument et une désorganisation structurelle des cellules à la fois tégumentaires et non tégumentaires. Ces altérations augmentent vers le $7 \mathrm{e}$ jour après le traitement ; la vacuolisation s'étend, le nombre des corps en baguette diminue et l'œdème se généralise. Au bout de 10 jours, l'œdème intracellulaire devient plus saillant et produit des phlyctènes de tailles variables. L'œdème intracellulaire qui conduit à ces lésions bulleuses semble être le caractère le plus frappant dû au traitement à l'oxamniquine.

\section{Introduction}

In a recent light microscopical study (Kohn et al., 1979b) some of the morphological alterations induced by oxamniquine on $S$. mansoni adult worms were reported. Brasil.

* Departamento de Helmintologia, Instituto Oswaldo Cruz, Fiocruz, C.P. 926, Rio de Janeiro, RJ,

** Laboratorio de Microscopia Eletrônica, Instituto de Microbiologia, Univ. Federal do Rio de Janeiro, RJ, Brasil.

*** Centro de Pesquisas René-Rachou, Fiocruz, Belo Horizonte, MG, Brasil.

Supported in part by CNPq and FINEP, Brasil.

Accepté le I7 novembre I $98_{9}$. 
At the present, an ultrastructural study using both transmission and scanning electron microscopy was performed in order to clarify some aspects of the lesions caused by the drug in the tegumental and subtegumental tissues of the male worm.

\section{Material and methods}

White swiss mice (18-20 g) were subcutaneously inoculated with cercariae from LE strain of $S$. mansoni ( $100 \pm 20$ per mouse). These cercariae were obtained from laboratory reared and infected Biomphalaria glabrata. Forty-five days after inoculation, the infected mice were treated with a single oral dose of oxamniquine $(100 \mathrm{mg} / \mathrm{Kg}$ ) and sacrificed respectively 24 hours, 3,7 and 10 days after treatment. Controls consisting of untreated infected mice were used. The worms were recovered and processed for transmission electron microscopy as described previously (Kohn et al., 1979a). Samples of these parasites, obtained 10 days after drug treatment, were also processed for scanning electron microscopical studies. These worms were fixed in $3 \%$ glutaraldehyde in $0.1 \mathrm{M}$ cacodylate buffer ph 7.4 at $4^{\circ} \mathrm{C}$, post fixed in $2 \%$ osmium tetroxide and dehydrated in a graded series of ethanol or acetone. They were desiccated in a critical point dryer (Balzer Union, Lichstein), oriented and mounted on aluminium stubs, sputtered with gold and examined with a Jeol J.S.M. 25S II Scanning Electron Microscope at $12.5 \mathrm{KV}$.

\section{Results and discussion}

The tegument ultrastructure of untreated male schistosomes was essentially as described by previous workers (Morris and Threadgold, 1968; Hockley, 1973; Wilson and Barnes, 1974).

The male worms collected 24 hours after drug administration presented initial alterations such as the presence of small vacuoles formed by expanded basal membrane invaginations. Three days after oxamniquine treatment, the basal vacuolation of the tegument in male worms was highly significant. Simultaneously, oedema, membrane whorls and myelin-like figures were also observed in the tegument as well as in the non tegumental cells. After seven days (fig. 1) besides the vacuolation of the syncytial tegumental layer, myelin-like figures and a decreased number of rod-shaped bodies were also detected. These facts were also observed in the

FIG. I-2. - Schistosoma mansoni male dorsal tegument after oxamniquine treatment. Fig. I: TEM of a 7 days period treatment showing basal vacuolation (V), myelin-like figure (FM), lysosomes (gross black arrow) and scarses rod-bodies (narrows arrows). A basal membrane separate the integument from the underlying microfibrils (F) and muscle fibers (M), X 36.000 . Fig. 2: TEM of a ro days period treatment. Low magnification (inset) shows marked alterations in the tegumental, muscular and parenchymal levels. The tubercles (B) containing several espines (E) are also abnormal in aspect, X 1.80o. At higher magnification the autolytic changes including multilaminated vesicles (black arrow), epithelial vacuolar transformation and extracellular œdema, with disorganization of the microfibrillar network can be appreciated, X ro.ooo. 

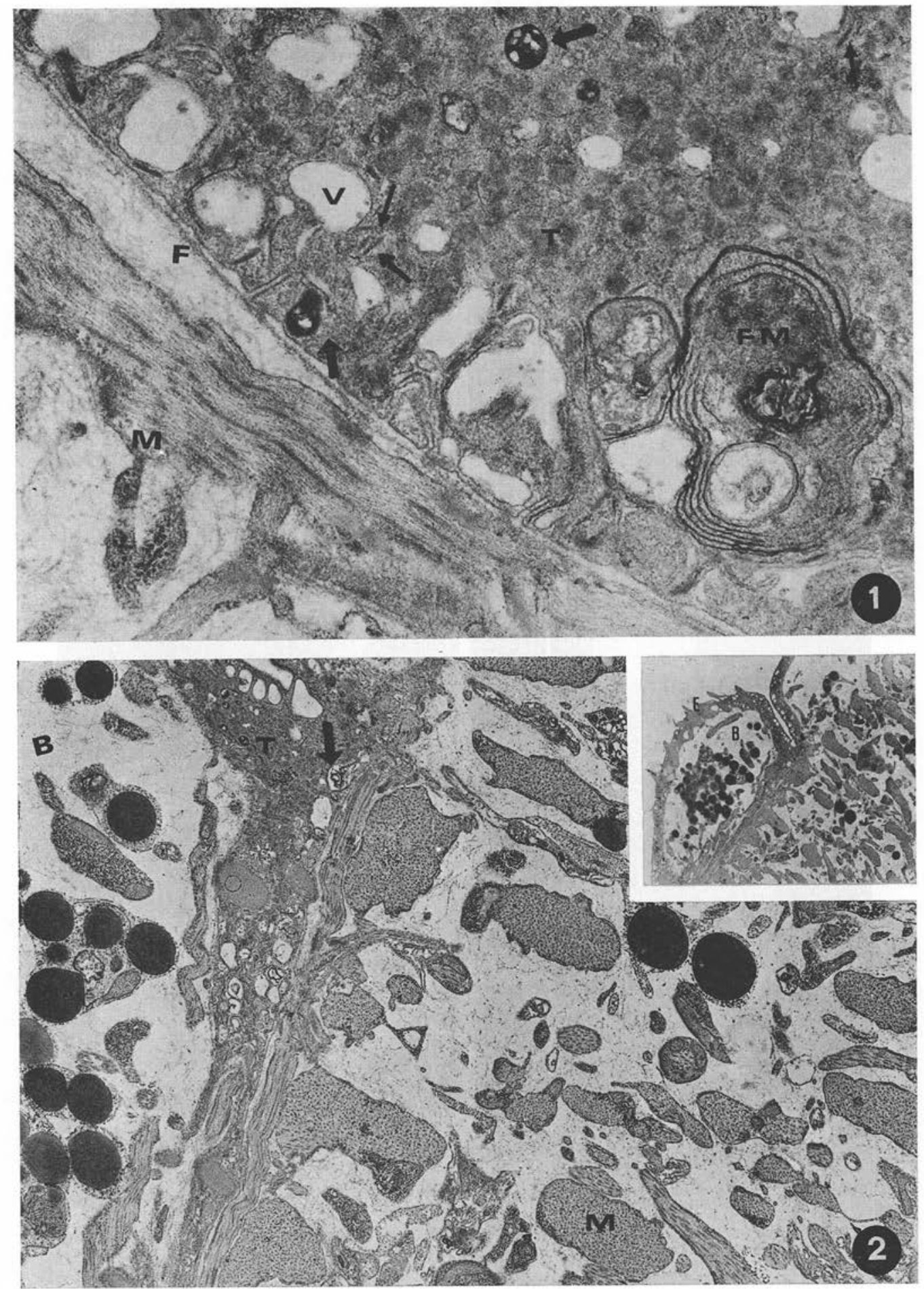

FIG. I et 2. 

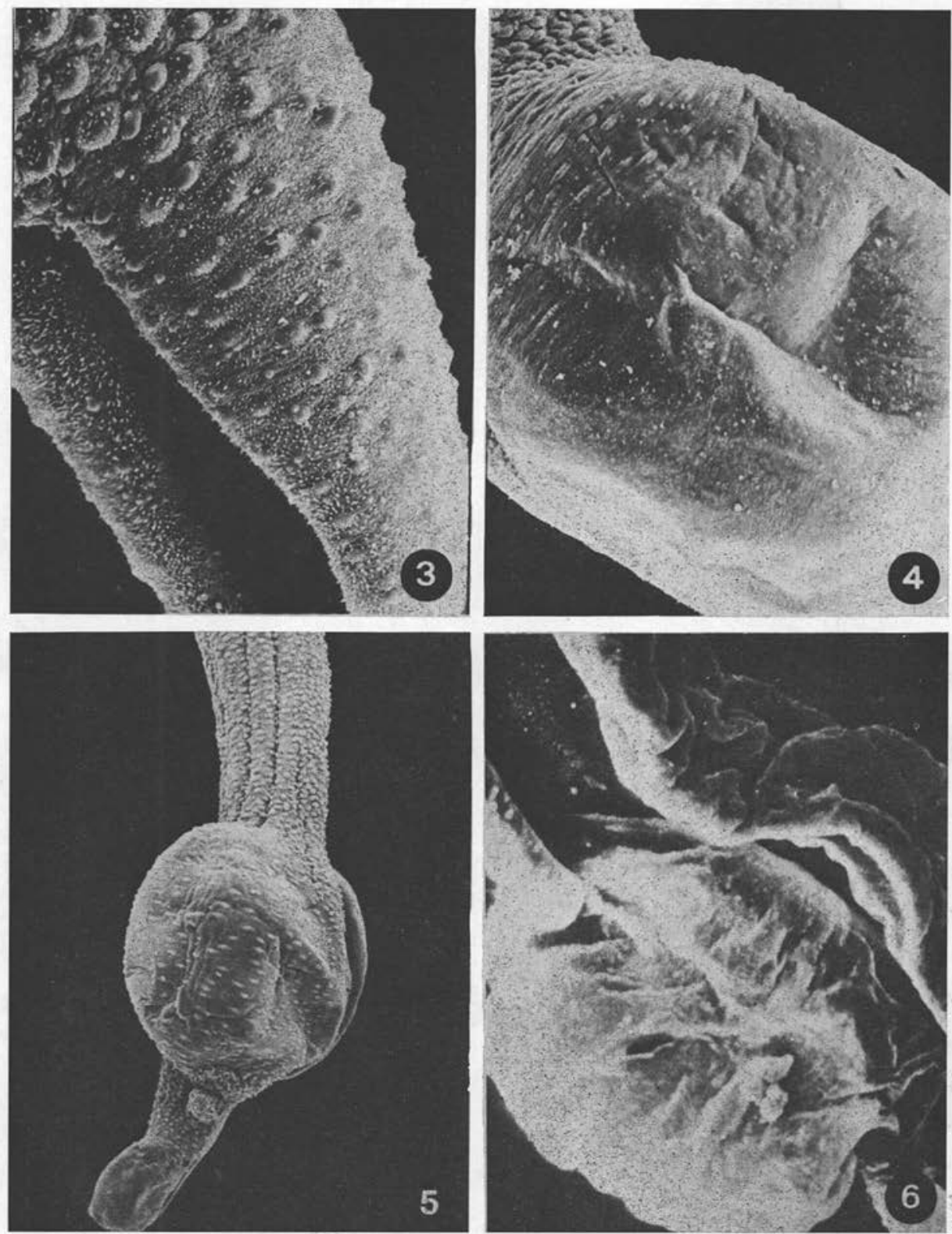

FIG. 3. - SEM of the posterior extremity of male $S$, mansoni untreated control. Some disperse tubercles and many spines as well as the caudal end of the gymnaecophoral canal are visible, $\mathrm{X} 750$.

FIG. 4. - "Buble" lesion on the posterior extremity of male S. mansoni ro days after oxamniquine treatment, $\mathrm{X} 300$,

FIG. 5. - Two "bubble" lesions of varied size on the caudal end of the worm, Io days after treatment, X 70 .

FIG. 6. - "Bubble" lesion on the dorsolateral middle region of the parasite, ro days after treatment, $\mathrm{X}+8 \mathrm{o}$. 

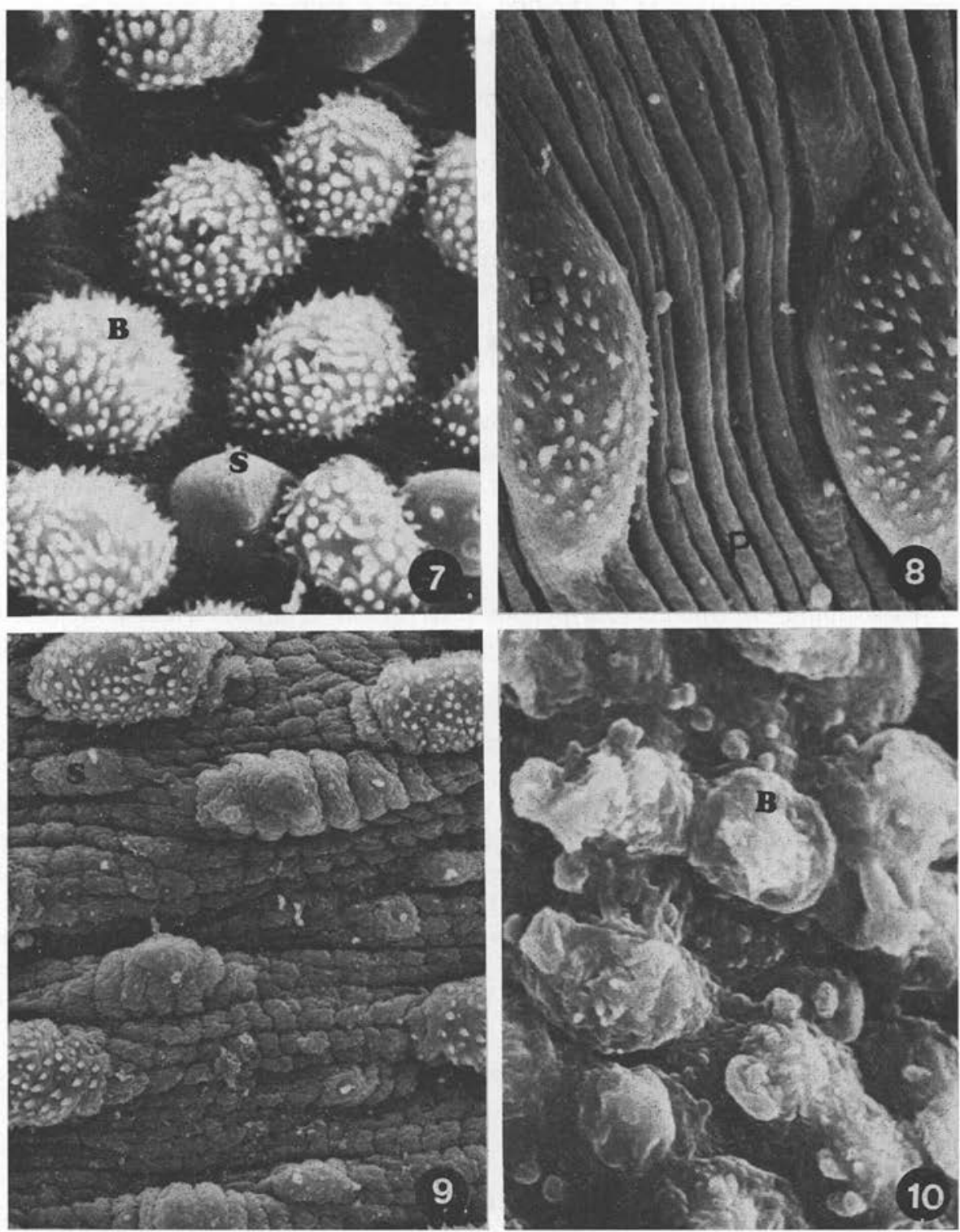

FIG. 7. - SEM of dorsal surface of male $S$. mansoni untreated control, showing tubercles (B), spines and sensory bulbs (S), X r.80o.

Fig. 8. - Non damage region of the dorsal surface of a male worm ro days after treatment, showing their characteristics folds and pits (P) and the bosses (B) with spines and numerous small pores, X 2.000.

FIG. 9. - Oedema and sensory bulbs (S) highly damaged on dorsal surface of a male S. mansoni Io days after drug treatment, X I.500.

FIG. Io. - Area highly affected of the dorsal tegument of a male worm ro days after treatment. Collapsed tubercles (B), disruption of the sensory bulbs and lost of the normal pattern surface are shown, X r.80o. 
subtegumental cell bodies. These cells presented dilated endoplasmic reticulum cisternae, increased number of lysosomes and myelin-like figures. Generalized oedema in the parenchyma and disaggregation of the underlying myofibrilar system were also observed. Ten days after treatment ( $f$ ig. 2), there was a gradual increase of alterations in the structure of $S$. mansoni males. There was an extensive vacuolation of the tegument, an increase in the intercellular spaces, fragmentation and retraction of the muscle fibers and an intense oedema. In general, less vacuolation was seen on the ventral surface. The typical tubercles undergone considerable changes, becoming oedematous, vacuolated and abnormal in appearance. It was noted that the rate of degeneration varied not only in individual worms but also from one region to another (fig. 8), as was also observed by Becker et al. (1980) in praziquantel treated worms. The most striking alteration was the formation of large "bubble-like" lesions, only observed in male worms, principally on the dorsal surface, posterior to the ventral sucker. These bubble lesions were formed by extensive areas of oedema intermingled with disorganized connective microfibrils in abnormal areas under the tegument. These "bubbles" were externally visible as tegumental elevations.

By scanning electron microscopy, our observations as to the surface of untreated S. mansoni males (fig. 3,7 ) are in accordance to those previously described (Miller et al., 1972; Miegeville et al., 1978).

The surface of male worms recovered from mice ten days after treatment with oxamniquine showed, by SEM, alterations when compared with the control worms. The most significant morphological degeneration was the typical "bubble-like" lesion detected in most of the recovered worms. These lesions may present a focal distribution in the worm or be diffuse (fig. 4-6), corroborating the results of Voge and Bueding (1980) with amoscanate treatment. Changes in the aspect and form of the tubercles and sensory bulbs wich appeared collapsed and disrupted, were frequently observed. Simultaneously, swelling of the tegumental surface, reduction in the height and number of the surface pits and channels as well as in the number of tegumentary bosses and spines in the bubble region, were also noted ( fig. 9, 10).

Acknowledgements. We are grateful to Prof. R.D. Machado for his collaboration.

\section{REFERENCES}

Becker B., Mehlhorn H., Andrews P., Thomas H., Eckert J. : Light and electron Microscopic studies on the effect of praziquantel on Schistosoma mansoni, Dicrocoelium dendriticum, and Fasciola hepatica (Trematoda) in vitro. Z. Parasitenkd., 1980, 63, Ir $13-128$.

Hockley D. J. : Ultrastructure of the tegument of Schistosoma. Adv. Parasitol., I973, I1, 233-305.

Kohn A., Cotta-Pereira G., Lopez-Alvarez M. L., Kattenbach W. M. : Oxytalan fibers in the Schistosoma mansoni tegument. Rev. Bras. Pesquisas Méd. Biol., I979a, 12, 335-338.

Kohn A., Serapiao C. J., Katz N., Dias E. P. : Açao da oxamniquine sobre o Schistosoma mansoni em camundongos experimentalmente infectados. Rev. Inst. Med. trop. Sao Paulo, 1979b, 21, 21 7-227. 
Miegeville M., Marjolet M., Vermeil C. : Observations de Schistosoma mansoni en microscopie électronique à balayage. C. R. Acad. Sci., Paris, 1978, 286, 901-903.

Miller F. H., Tulloch G. S., Kuntz R. E. : Scanning electron microscopy of integumental surface of Schistosoma mansoni. J. Parasitol., 1972, \&8, 693-698.

Morris G. P., Threadgold L. T. : Ultrastructure of the tegument of adult Schistosoma mansoni. J. Parasitol., 1968, 54, I5-27.

VOGE M., BUEDING E. : Schistosoma mansoni tegumental surface alterations induced by subcurative doses of the schistosomicide Amoscanate. Exp. Parasit., 1980, 50, 251-259.

Wilson R. A., Barnes P. E. : An in vitro investigation of dynamic processes occurring in the schistosome tegument, using compounds known to disrupt secretory processes. Parasitol., $1974,68,259-270$. 